\title{
ANALISIS KARAKTERISTIK KHUSUS TEKS NEGOSIASI
}

\author{
Mahmudah Nursolihah ${ }^{\mathbf{1}}$ dan Mia Widianti ${ }^{2}$ \\ Program Studi Pendidikan Bahasa dan Sastra Indonesia \\ Sekolah Tinggi Keguruan dan Ilmu Pendidikan (STKIP) Pancakarya Tangerang \\ Surel: madujrs@gmail.com
}

\begin{abstract}
Abstrak
Teks negosiasi menjadi salah satu bahan ajar di dalam kurikulum 2013, tepatnya dipelajari di kelas X. Pada bahan ajar tersebut hanya mempelajari tentang struktur dan kaidah kebahasaan. Akan tetapi pada tahap implementasi, terdapat banyak hal yang penting untuk diketahui guna mencapai tujuan negosiasi. Dengan demikian, materi negosiasi yang dipelajari di sekolah dianggap kurang relevan dengan negosiasi yang terjadi di dunia nyata. Oleh karena itu, artikel ini bertujuan untuk memaparkan tentang struktur, kebahasaan, dan faktor-faktor yang memengaruhi keberhasilan dalam bernegosiasi. Artikel ini juga memaparkan proses negosiasi yang secara riil terjadi di tengah-tengah masyarakat. Metode yang digunakan dalam artikel ini adalah studi kepustakaan dengan pengambilan data melalui aktivitas mengamati kegiatan negosiasi dari bidang jual beli, hukum, dan politik. Berdasarkan hasil analisis yang telah dilakukan maka didapatkan hasil bahwa dalam bidang jual beli, hukum, dan juga bidang politik memiliki proses, struktur, dan faktor yang mempengaruhi keberhasilan negosiasi yang berbeda. Selain itu juga ditemukan ketidaksesuaian antara materi yang dipelajari siswa dengan situasi di lapangan. Pada buku materi ajar, negosiasi dibahas dengan konsep yang sederhana
\end{abstract}

Kata Kunci: karakteristik khusus, negosiasi, dan bahan ajar.

\section{Abstract}

The negotiating text is one of the teaching materials in the 2013 curriculum, precisely learned in class X. In the teaching material only learns about the structure and rules of language. However, at the implementation stage, there are many important things to know in order to achieve the objectives of the negotiations. Thus, the negotiation material learned in schools is considered to be less relevant to negotiations taking place in the real world. Therefore, this article aims to describe the structure, language and factors that influence the success in negotiations. This article also describes the negotiation process that actually takes place in the midst of society. The method used in this article is the study of literature by collecting data through observing the activities of negotiation from the field of buying and selling, law, and politics. Based on the results of the analysis that has been done, the results are obtained that in the field of buying and selling, law, and also the political field has a process, structure, and factors that affect the success of different negotiations. It also can be said that the negotiation process in the community was not in accordance with the negotiating text material taught in schools. In textbooks, negotiations are discussed with a simple concept.

Keywords: special characteristics, negotiations, and teaching materials. 


\section{PENDAHULUAN}

Salah satu dari sekian bentuk interaksi manusia yang digunakan untuk keperluan mendapatkan persetujuan atau kesepakatan bersama, dikenal dengan istilah negosiasi. Negosiasi merupakan suatu proses perundingan antara dua pihak atau lebih yang berbeda pendapat tentang suatu permasalahan yang membutuhkan kesepakatan bersama. Selain itu, negosiasi merupakan cara yang paling efektif untuk mengatasi dan menyelesaikan konflik atau perbedaan kepentingan.

Dewasa ini, di bidang pendidikan menerapkan kurikulum baru, yaitu kurikulum 2013. Dalam kurikulum tersebut, negosiasi dijadikan sebagai materi pembelajaran. Pembahasan negosiasi ini berdasarkan kepada teks. Adapun yang dipelajarinya yaitu bagaimana struktur teks negosiasi, ciri kebahasaan teks negosiasi, serta cara penyampaian, pengajuan, dan penawaran.

Teori-teori teks negosiasi yang dipelajari di kelas kurang lengkap. Sehingga terkadang pada penerapan-nesia da nya antara kegiatan bernegosiasi dan teori yang dipelajari di sekolah tidak selaras. Karena dalam materi yang dipelajari tidak membahas secara luas tentang hal-hal lain yang berkaitan dengan negosiasi, misalnya mengenai pertimbangan untung-ruginya, faktor yang mempengaruhi keberhasilan, dan sebagainya.
Berdasarkan pemaparan tersebut, maka kami tertarik mengadakan suatu penelitian mengenai negosiasi. Oleh karena negosiasi ini merupakan aktivitas urgent yang mendukung kelancaran urusan hidup manusia, maka hal-hal yang akan diteliti adalah bagaimana proses negosiasi hingga mencapai kesepakatan dan faktor apa saja yang mendukung keberhasilan dalam bernegosiasi. Selain itu, penelitian ini bermaksud untuk menyesuaikan antara teori yang dipelajari di sekolah dengan penerapannya di masyarakat.

Negosiasi merupakan sebuah bentuk interaksi sosial ketika beberapa pihak terlibat untuk menyelesaikan sebuah tujuan yang bertentangan, atau bisa diartikan sebagai salah satu bentuk interaksi sosial diantar dua belah pihak atau pun lebih dengan memiliki tujuan untuk mencapai kesepakatan bersama dimana setiap pihak saling diuntungkan.

Menurut Jackman (2005: 8) negosiasi merupakan sebuah proses yang terjadi antara dua pihak atau lebih yang pada mulanya memiliki pemikiran berbeda, hingga akhirnya mencapai kesepakatan. Negosiasi disebut pula sebagai proses interaktif yang dilakukan untuk mencapai persetujuan. Proses ini melibatkan dua orang atau lebih yang memiliki pandangan berbeda tetapi ingin mencapai beberapa resolusi bersama. (McGuire, 2004: 23).

Secara ringkas dapat dirumuskan bahwa negosiasi adalah proses perundingan antara para pihak yang berselisih atau berbeda pendapat tentang sesuatu permasalahan. Adapun tujuan dari negosiasi adalah sebagai berikut. 
a. Menemukan suatu kesepakatan kedua pihak secara adil dan dapat memenuhi harapan kedua pihak.

b. Mendapatkan sebuah keuntungan atau menghindarkan kerugian atau memecahkan masalah masalah.

Adapun gambaran umum proses negosiasi yang diungkapkan dalam (Robert, 1997: 7) antara lain:

1) relatif tidak berstruktur;

2) tidak ada aturan prosedur yang baku;

3) tidak ada agenda yang baku atau sama;

4) tiap-tiap pihak memperjuangkan kepentingannya masing-masing;

5) melibatkan proses pembicaran, mendengarkan, dan pengamatan;

6) tujuannya adalah untuk mencapai suatu kesepakatan yang dapat diterima oleh kedua belah pihak;

7) proses negosiasi adalah milik pihakpihak yang terkait: tidak dihadiri oleh pihak ketiga yang independen, kecuali jika negosiasi macet atau mencapai deadlock dan kemudian ditunjuk seorang konsiliator atau penengah untuk membantu dalam proses perundingan; dan

8) negosiasi tidak selalu berakhir dengan kesepakatan; kedua belah pihak mungkin saja dapat menyetujui ketidaksepakatan Jyang terjadi

Negosiasi melibatkan persuasi/ bujukan untuk mencapai suatu maksud dan kompromi yang konstruktif/ membangun.

Terdapat beberapa hasil penelitian para ahli mengenai faktor-faktor yang mempengaruhi keberhasilan dalam bernegosiasi, berikut perinciannya menurut Mc Guire (2004: 24) terdapat tiga faktor utama dalam kemampuan negosiasi yang baik, yaitu sebagai berikut.

\section{a. Patience}

Negosiator yang baik menyadari bahwa negosiasi membutuhkan proses, termasuk di dalamnya untuk menghilangkan sekat diantara kedua pihak dan bukan merupakan hasil instan.

\section{b. Self Confidence}

Negosiator yang baik menyadari bahwa dengan memiliki kepercayaan diri berarti memiliki pula keyakinan akan kemampuannya untuk mencapai keberhasilan negosiasi.

\section{c. Communication Skill}

Negosiator yang baik menyadari bahwa dengan melibatkan dua pihak, negosiasi membutuhkan kemampuan komunikasi yang baik agar mampu menangkap pesan secara efektif.

d. Ethics

Etika merupakan sebuah studi yang membicarakan perbuatan atau tingkah laku manusia, mana yang dinilai baik dan buruk. Etika juga disebut ilmu normatif, yakni berisi ketentuan-ketentuan (normanorma) yang dapat digunakan sebagai acuan untuk menilai tingkah laku baik atau buruk

Chia Jung Tsay (2009:10) mengungkapkan bahwa, Ethical standards in negotiation are critical to understanding the nature of the negotiation game. Kesalahan dalam etika yaitu bahasa yang tidak pas dan tidak menghargai waktu lawan/partner

e. Psichology

Mengerti kondisi psikologi mitra negosiasi, yakni mampu menerima sudut pandang mitra yang mungkin berbeda dan mampu melakukan pendekatan yang logis untuk menciptakan dan mempertahankan 
hubungan yang baik, saling menguntungkan, dan saling menghormati.

f. Emotion

Menurut Elena, Liljana, Kliment (2012: 197) bahwa, "In the negotiations, especially the ones that lead towards an argument, very often the emotions may be more important than words. The parties may be ready for a fight instead of a cooperative collaboration aimed towards finding a solution for the common problem. It is a fact that the emotions of one party will provoke emotions in the other party too. The ability to recognize someone else's emotions as well as yours may be vital for avoiding their interference in the process of negotiation".

Emosi memainkan peran penting dalam proses negosiasi. Emosi berpotensi memainkan peran positif atau negatif dalam negosiasi. Selama bernegosiasi, keputusan sebagian didasarkan pada faktor emosional.

Emosi negatif dapat menyebabkan perilaku intens, bahkan tidak masuk akal, dan dapat menyebabkan konflik meningkat dan negosiasi mereda, akan tetapi berperan dalam mencapai konsesi. Di sisi lain, emosi positif sering memfasilitasi mencapai kesepakatan dan membantu memaksimalkan keuntungan bersama, dan dapat berperan dalam mencapai konsesi.

g. Retorika

Retorika merupakan kesenian untuk berbicara baik yang dipergunakan dalam proses komunikasi antarmanusia. St. Agustinus (dalam Jalaludin, 2011: 85) mengatakan bahwa kepandaian berbicara adalah seni yang mencakup segalagalanya. Menguasai kesanggupan berbahasa dan keterampilan berbicara menjadi alasan utama keberhasilan orang- orang terkenal di dalam Sejarah Dunia seperti: Demosthenes, Socrates, J. Caesar, St. Agustinus.

Dalam bahasa percakapan atau bahasa populer, retorika berarti pada tempat yang tepat, pada waktu yang tepat atas cara yang lebih efektif, mengucapkan kata-kata yang tepat, benar, dan mengesankan. Sehingga urgensi retorika dalam negosiasi bertumpu pada kemampuan komunikasi, karena dalam negosiasi, kemampuan komunikasi merupakan aspek mendasar yang akan mempengaruhi keberhasilan dalam bernegosiasi, dan bisa dipastikan bahwa seorang yang menguasai teknik retorika secara baik pasti mampu berkomunikasi secara efektif dan efisien.

h. Nonverbal Communication

Komunikasi adalah elemen kunci dalam negosiasi. Negosiasi yang efektif mengharuskan peserta menyampaikan dan menafsirkan informasi secara efektif. Peserta dalam negosiasi akan mengkomunikasikan informasi tidak hanya secara verbal namun non-verbal melalui bahasa tubuh dan gerak tubuh.

Menurut Hais Dama bahwa komunikasi nonverbal adalah komunikasi yang dilakukan manusia bukan dengan menggunakan katakata, melainkan dengan menggunakan gerakan-gerakan tubuh, bahasa tubuh (body language). Misalnya, menggertakan gigi sebagai tanda sedang marah, mengerutkan dahi sebagai tanda sedang berpikir keras, atau menganggukan kepala sebagai tanda mengiyakan atau mengerti.

Dalam Robert (1997 : 11) diungkapkan bahwa tahapan-tahapan dalam bernegosiasi sebagai berikut: 
1. Tahap persiapan

Tahap persiapan ini mencakup penentuan sasaran dan prioritas, mengumpulkan informasi, dan menentukan strategi yang akan digunakan.

2. Tahap diskusi

Dalam negosiasi-negosiasi yang lebih formal, ada tahap pendahuluan dimana kedua belah pihak saling diperkenalkan terlebih dahulu, saling mengklarifikasi masalah, menyepakati urutan-urutan masalah yang akan dinegosiasikan, dan menentukan bagaimana dan kapan terjadi jeda waktu dalam proses negosiasi.

Dalam tahap diskusi terbagi menjadi beberapa tahap sebagai berikut.

a. Tahap pernyataan pembukaan

Diskusi tentang negosiasi biasanya dimulai dengan pernyataan pembukaan oleh kedua belah pihak. Pihak yang mengajukan tuntutan adalah yang mendapatkan kesempatan pertama terlebih dahulu. Tahap ini adalah tahap dimana masing-msing pihak menyajikan kasusnya secara umum, mengklarifikasi posisi masingmasing dan menegaskan pandangan mereka terhadap tiap masalah.

b. Tahap perundingan (tawar-menawar) tilikiah

Tahap perundingan ini mencakupesia daPembelil: "Kang, ada laptop Asus i3 tentang usulan penawaran konsesi dan mengarah kepada suatu kesepakatan.

c. Penutup dan Kesepakatan

Pada tahap ini kedua belah pihak secara aktif mencari posisi menang-menang dan mencapai suatu kesepakatan yang dapat diterima bersama.

\section{METODE}

Metode yang digunakan dalam artikel ini adalah studi kepustakaan dengan pengambilan data melalui aktivitas mengamati dan mennegosiasi masyarakat di berbagai bidang dalam beberapa jenis interaksi maupun media.

\section{HASIL DAN PEMBAHASAN}

Peneliti telah melakukan penelitian terhadap negosiasi yang terjadi di masyarakat. Data yang diambil meliputi data jual beli, bidang hukum, dan politik. Data-data tersebut akan dipaparkan satu persatu di bawah ini.

\section{Data Jual Beli}

Data jual beli ini diambil dari berbagai sumber, yakni dari hasil pengamatan di pasar Palasari dan Gasibu, juga di media sosial, yakni facebook dan televisi. Berikut adalah salah satu data yang didapatkan di pusat perbelanjaan elektronik di Bandung (BEC) pada tanggal 27 Agustus 2017. Negosiasi ini terjadi antara penjual laptop dan calon pembelinya. dengarkan secara langsung aktivitas 
ini juga sedang booming dan banyak peminat. Ambil 5. 200.000 aja teh." Pembeli : "Wah, mahal ya kang."

Penjual : "Teteh boleh cek ke tempattempat lain di BEC ini, biasanya mereka jual standar 5.400.000 sampai 5.700.000."

Pembeli : “Apa saja keunggulan laptop Asus i3 pro ini kang?"

Penjual : "RAMnya 4 GB dengan performa tangguh dan spesifikasi mumpuni dan mudah mengerjakan perkerjaan-pekerjaan berat seperti multimedia, menonton video online dari youtube atau situs sejenisnya, Apalagi hanya untuk browsing, membuat tugas dokumen, pindah file dan menjalankan musik. Dengan core i3 juga tidak ada halangan untuk anda membuka banyak aplikasi atau kegiatan dalam waktu yang sama."

Pembeli : "Ya udah Kang kurang dagl tlmiah 5 juta aja ya?" Indonesia dar murah dibandingkan di tempat lain.

Penjual : "Gak bisa teh, bener deh. Coba aja teteh keliling di BEC ini, harganya pasti kisaran $\quad 5.400 .000-$ 5.700.000.”

Pembeli : "Dengan harga segitu dapat apa aja kang? Kalau bermasalah nanti bagaimana?"
Penjual : "Garansi 2 tahun, yakni satu tahun dari perusahaan dan satu tahun dari kami. Kalau terjadi apa-apa silahkan datang ke sini."

Pembeli : "Ini beneran gak bisa di bawah 5 juta Kang? 5 juta pas aja deh kalau gitu"

Penjual : "Wah maaf banget teh tetap gak bisa, ini sudah harga pas."

Pembeli : "Ayolah Kang, kantong mahasiswa terbatas" (sembari tertawa kecil)

Penjual : "Begini saja teh, 5.100.000 saja, itu teteh sudah dapat mouse, tas, dan keyboard protector. Beneran teh, ini sudah harga paling murah."

Pembeli : "Baiklah, Kan. Laptopnya jadi saya beli."

Dalam negosiasi yang terjadi, penjual menggunakan kalimat-kalimat persuasi untuk memengaruhi pembeli agar membeli barangnya. Kalimatkalimat tersebut di antaranya dia berusaha meyakinkan pembeli bahwa

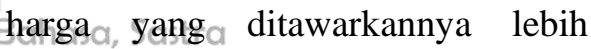

Selain itu, ketika penjual menolak harga yang ditawarkan pembeli dan menurunkan sedikit dari harga awal yang ditawarkan oleh penjual, penjual meyakinkan kembali pada pembeli dengan harga Rp5.100.000,00 dia sudah mendapat keuntungan lebih, seperti mouse, garansi, dan tas laptop. Tidak hanya penjual, pembeli pun 
merayu penjual agar dia dapat menurunkan harga yang ditawarkannya. Pembeli merayunya dengan alasan bahwa dia adalah seorang mahasiswa yang hanya memiliki uang terbatas dan belum ada penghasilan. Pembeli berharap penjual merasa empati dengan keadaannya sehingga dapat menurunkan harga yang ditawarkannya.

Pada data negosiasi dalam bidang jual beli ini, peneliti menemukan 15 data yang serupa. Setelah dianalisis, data-data tersebut mengawali negosiasi dengan menanyakan barang yang dicari oleh pembeli, kemudian berlanjut pada proses tawar-menawar harga, kesepakatan, dan penutup. Akan tetapi ada beberapa negosiasi yang terjadi tidak menggunakan penutup, hanya sampai pada kesepakatan saja. Selain itu, pada proses negosiasi ada beberapa yang memaparkan alasan-alasan untuk mencapai harga yang diinginkan, baik dari pihak penjual ataupun pembeli dan ada juga yang tidak. Akan tetapi, pada banyak negosiasi berusaha menggunakan alasan-alasan agar kesepakatan yang dicapai sesuai dengan keinginannya.

Alasan-alasan yang digunakan penjual agar pembeli membayar dengan harga yang diinginkannya adalah karena harga yang diberikannya lebih murah dibandingkan di tempat yang lain.

Selain itu, penjual menolak tawaran harga pembeli dengan alasan bahwa harga yang ditawarkannya hanya modalnya saja, sehingga penjual tidak mendapatkan keuntungan. Tidak hanya penjual, mayoritas pembeli pun memberikan alasan kenapa penjual harus menerima tawaran harganya/menurunkan harga.

Alasan-alasan yang biasa digunakan pembeli adalah karena pembeli merupakan mahasiswa yang belum dapat menghasilkan uang sendiri. Pembeli juga meminta diturunkan harganya dengan melihat kualitas barangnya. Selain itu, biasanya pembeli menggunakan alasan hubungan kedekatan.

\section{Karakteristik Khsusus}

Kaidah Khsusus ini meliputi proses negosiasi, lama pelaksanaan proses negosiasi, faktor yang mempengaruhi keberhasilan bernegosiasi, dan tercapainya hasil atau keputusan dalam bernegosiasi. Pada proses jual beli, adapun kaidah khsusus yang berlaku adalah sebagai berikut.

\section{Tabel 1.}

\section{Kaidah Khusus Data Jual Beli}

\begin{tabular}{|l|c|}
\hline $\begin{array}{l}\text { Proses } \\
\text { Negosiasi }\end{array}$ & $\begin{array}{c}\text { Proses negosiasi } \\
\text { trajadi antara } \\
\text { dua belah pihak } \\
\text { Daerah }\end{array}$ \\
yakni penjual \\
dan pembeli, \\
proses negosiasi \\
pun terjadi \\
secara langsung \\
tanpa diatur atau \\
dikomando oleh \\
siapapun. \\
\hline
\end{tabular}




\begin{tabular}{|c|c|c|}
\hline $\begin{array}{l}\text { Lama } \\
\text { Pelaksanaan }\end{array}$ & $\begin{array}{c}\text { Durasi } \\
\text { terjadinya } \\
\text { proses negosiasi } \\
\text { pada jual beli } \\
\text { adalah sejak } \\
\text { awal sampai } \\
\text { akhir, yakni } \\
\text { dimulai setelah } \\
\text { pembeli } \\
\text { menanyakan } \\
\text { harga kepada } \\
\text { penjual. }\end{array}$ & $\begin{array}{l}\text { Data Hukum } \\
\text { Data hukum pada penelitian ini } \\
\text { didapat dari media sosial, yaitu } \\
\text { artikel-artikel dari internet dan } \\
\text { tayangan yang ada di Youtube. Berikut } \\
\text { adalah salah satu data dibidang hukum } \\
\text { yang ditemukan oleh peneliti, } \\
\text { mengenai kasus persidangan Jessica } \\
\text { Kumala Wongso. } \\
\text { Mirna dinyatakan meninggal pada } \\
6 \text { Januari } 2016 \text { setelah meminum kopi } \\
\text { bersama teman-temannya Hani dan }\end{array}$ \\
\hline $\begin{array}{l}\text { Faktor yang } \\
\text { mempengaruhi } \\
\text { keberhasilan }\end{array}$ & $\begin{array}{l}\text { Adapun faktor } \\
\text { yang } \\
\text { mempengaruhi } \\
\text { keberhasilan } \\
\text { bernegosiasi } \\
\text { dalam proses } \\
\text { jual beli adalah } \\
\text { kemampuan } \\
\text { retorika atau } \\
\text { communication } \\
\text { skill, tingkat } \\
\text { kesabaran, dan } \\
\text { kemampuan } \\
\text { mengelola } \\
\text { emosi . }\end{array}$ & $\begin{array}{l}\text { Jessica. Diduga Mirna meningga } \\
\text { akibat keracunan sianida. Pad } \\
\text { peristiwa kematian Mirna ini, Jessic } \\
\text { dicuragai sebagai pembunuh ole } \\
\text { pihak keluarga Mirna. Dengan dali } \\
\text { mencari keadilan, pihak keluarg } \\
\text { Mirna pun membawa kasus ini ke jalu } \\
\text { hukum. } \\
\text { Dari hasil penyidikan da } \\
\text { berbagai keterangan, diketahui Mirna } \\
\text { Hani, dan Jessica adalah teman seja } \\
\text { kuliah yang sudah lama tidak bertemu } \\
\text { Pada tanggal } 6 \text { Januari } 2016 \text { merek } \\
\text { berencana untuk bertemu melepa } \\
\text { rindu di Olivier Cafe. Jessica yan }\end{array}$ \\
\hline Keputusan & $\begin{array}{c}\text { Adapun hasil } \\
\text { atau tujuan } \\
\text { bernegosiasiend } \\
\text { dalam jual beli } \\
\text { dihasilkan atas } \\
\text { kesepakatan } \\
\text { bersama dan } \\
\text { diketahui oleh } \\
\text { kedua belah } \\
\text { pihak. Bentuk } \\
\text { keputusannya } \\
\text { secara lisan dan } \\
\text { tindakan. }\end{array}$ & $\begin{array}{l}\text { tinggal di Australia sengaja pulang } \\
\text { Indonesia untuk menemui kedu } \\
\text { idikan temannya ini. Tepat dihari yang tela } \\
\text { fesia dalisepakati untuk bertemu, Jessic } \\
\text { lebih dulu sampai di lokasi temp } \\
\text { mereka akan bertemu. Karena Jessic } \\
\text { datang lebih awal, dia memesanka } \\
\text { minuman untuk Hani dan Mirn } \\
\text { dengan maksud agar ketika merek } \\
\text { datang minuman sudah siap. Karer } \\
\text { kejadian inilah Jessica menja } \\
\text { tersangka. }\end{array}$ \\
\hline
\end{tabular}


Persidangan atas kasus pembunuhan inipun berlangsung lebih dari 29 kali, di mana sidang ini mendatangkan ahli-ahli dari pihak Jaksa dan pihak tersangka. Sampai pada akhirnya jaksa membacakan tuntutan untuk Jessica. Pada tanggal 5 Oktober 2016 Jaksa Penuntut Umum (JPU) meminta pada hakim Pengadilan Negeri Jakarta Pusat agar menjatuhkan hukuman 20 tahun penjara kepada tersangka Jessica Kumala Wongso, karena bersalah melakukan tindakan pembunuhan yang direncanakan, sebagaimana melanggar pasal 340 KUHP.

Sementara pada tanggal 12 dan 17 Oktober 2016, pihak Jessica membacakan pledoi nota pembelaan sepanjang 3000 halaman. Beberapa inti dari pembelaan Jessica adalah sebagai berikut.

1. Mirna adalah teman baiknya yang tak mungkin ia tega untuk membunuhnya.

2. Tuduhan pembunuhan yang dilakukannya tak berdasar dan tak ia mengerti, Jessica merasa nama baik diri dan keluarganya telah dipojokkan dengan adanya tuduhan pembunuhan terhadapl Mirna.

3. Kehidupan penjara demikian membuatnya menderita dan mimpi buruk yang harus ia jalani.

4. Jessica menyayangkan dan menyesalkan kehidupan yang paling pribadinya yang tidak ada sangkut pautnya dengan kasus pembunuhan terhadap Mirna, juga ikut terangkat dan menjadi konsumsi publik.

Kuasa hukum Jessica, Otto Hasibuan, juga mengungkapkan beberapa kejanggalan dalam kasus ini, di antaranya adalah sebagai berikut.

1. Tidak ada bukti bahwa Mirna meninggal akibat sianida.

2. Tidak adanya otopsi terhadap jenazah Mirna.

3. Saksi penting operator CCTV tidak dihadirkan dalam persidangan.

4. Fisiognomi atau ilmu membaca karakter wajah yang dijadikan salah satu dasar ptnuntutan oleh jaksa, merupakan ilmu yang sudah ketinggalan zaman.

5. Telah terjadi manipulasi terhadap rekaman $C C T V$.

(Rappler.com publikasi, di-upload 19

Oktober 2016)

Setelah Jaksa membacakan tuntutan dan pihak Jessica memberikan pembelaan, tibalah giliran hakim untuk mempertimbangkan dan memutuskan tindakan selanjutya untuk kasus pembunuhan Mirna.

Bahdsada tanggal 27 Oktober 2016 HakimalPengadilan Negeri Jakarta Pusat memutuskan Jessica Kumala Wongso bersalah atas kematian Wayan Mirna Salihin. Hakim menyatakan Jessica terbukti melakukan tahapan pembunuhan berencana sesuai pasal 340 KUHP.

Berdasarkan penjelasan hakim, fakta persidangan menunjukan Jessica adalah orang yang paing memiliki 
kesempatan untuk memasukan racun sianida ke dalam es kopi Vietnam. Selama sekitar 55 menit, es kopi tersebut berada dalam penguasan Jessica yang lebih dulu datang ke Kafe Olivier dan memesankan minuman.

Hakim Kisworo juga mengatakan perbuatan Jessica juga memenuhi unsur kesengajaan. Hal tersebut dapat terlihat dari transkrip percakapan antara Jessica dan Mirna dimana Jessica meminta Mirna untuk membuatkan grup whatsapp untuk merencanakan pertemuan. Pada hari kejadian Jessica juga terus menerus bertanya tentang minuman yang diinginkan Mirna. Terdakwa juga langsung menghubungi Mirna saat pulang ke Indonesia.

Jessica juga dianggap memenuh unsur perencanaan. Hal ini terlihat dari keputusan Jessica yang langsung memutuskan pulang ke Indonesia dan berniat langsung menemui Mirna. Kepulangan Jessica tersebut dinilai hakim dilakukan Jessica untuk membalas dendam sakit hatinya kepada Mirna karena Mirna pernah menyarankan Jessica putus dengan pacarnya. Jessica juga terus menerus mengajak Mirna untuk bertemu. Pada hari kejadian, Jessica juga terus menerus menanyakan posisi Mirna.

Mendengar keputusan hakim tersebut, pihak Jessica tidak terima. Kuasa Hukum Jessica, menyatakan banding. Akan tetapi, hakim menolak permohonan banding yang diajukan oleh pihak Jessica.
Berdasarkan data di atas, peristiwa negosiasi terjadi ketika ada suatu kasus yang dilaporkan ke pengadilan. Dalam proses negosiasi dibidang hukum ini, ada dua pihak yang terlibat. Pihak tersebut adalah Jaksa Penuntut Umum (JPU) dan pihak terdakwa (tim pengacara). Negosiasi dibidang ini secara pelaksanaannaya begitu teratur.

Ketika negosiasi terjadi ada pihak yang memimpin jalannya negosiasi, yaitu hakim. Hakim berkedudukan sebagai pihak yang nantinya akan memutuskan dari negosiasi yang terjadi antara jaksa dan pengacara terdakwa. Negosiasi antara jaksa dan tim pengacara ini berlangsung lebih dari 29 kali.

Proses negosiasi diawali dengan menghadirkan para ahli yang telah mengamati kasus tersebut dari berbagai bidang. Ahli-ahli yang didatangkan tidak hanya dari pihak jaksa saja, di dalam persidangan juga didatangkan ahli dari pihak terdakwa. Setelah data yang dibutuhkan cukup menurut hakim, tahap selanjutnya yaitu pembacaan tuntutan dari jaksa untuka, s Jessica. Setelah jaksa membacakan tuntutan, maka giliran pihak Jessica yang membacakan pembelaannya.

Dari pembacaan tuntutan dan pembelaan, selanjutnya tugas hakim untuk mempertimbangkan hukuman yang sesuai untuk Jessica yang berdasarkan atas bukti-bukti dengan dihadirkannya para ahli, pembacaan tuntutan dan pembelaan. Kemudian 
hakim akan membacakan hasil keputusannya tersebut di dalam persidangan. Berdasarkan pemaparan tersebut, maka dapat disimpulkan tahap-tahap proses negosiasi dari data di atas dimulai dari pelaporan kasus ke persidangan, pemaparan para ahli, pembacaan tuntutan, pembacaan pembelaan, dan keputusan.

Selama proses negosiasi terjadi, bahasa yang digunakannya adalah bahasa Indonesia yang formal. Antara jaksa dan pengacara Jessica memberikan banyak bukti untuk dapat meyakinkan hakim agar memberikan keputusan sesuai yang diharapkan oleh jaksa ataupun oleh tim pengacara.

Dalam proses persidangan, jaksa mendatangkan ahli-ahli yang memberatkan Jessica. Begitupun tim pengacara Jessica mendatangka ahliahli yang meringankan Jessica.

\section{Karakteristik Khsusus}

Karakteristik khusus negosiasi dalam bidang hukum ini meliputi: bagaiamana proses negosiasi berlangsung, durasi atau lama pelaksanaan negosiasi, faktor-faktor yang mendukung tercapainya tujuan lidikan Bah asa, Sastra dalam bernegosiasi dan keputusanesia dan Daerah yang diperoleh dari hasil negosiasi.

\section{Tabel 3.}

Kaidah Khsusus Data Hukum

\begin{tabular}{|l|l|}
\hline Proses & Dalam negosiasi \\
Negosiasi & hukum ini, proses \\
& negosiasi \\
& berlangsung \\
& dengan ada yang \\
& memimpin atau \\
\hline
\end{tabular}

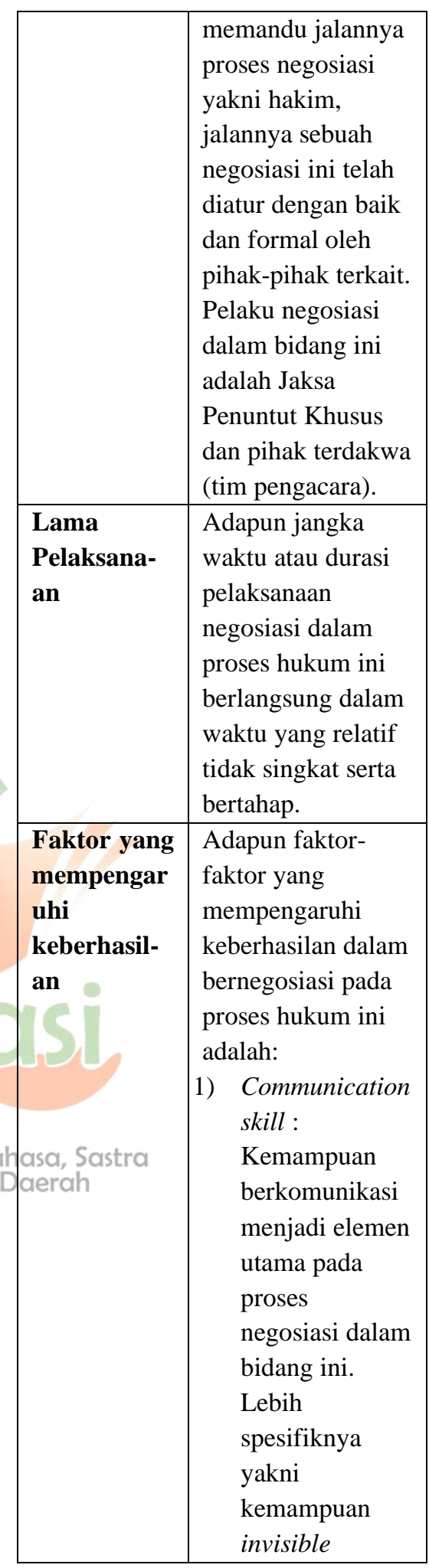




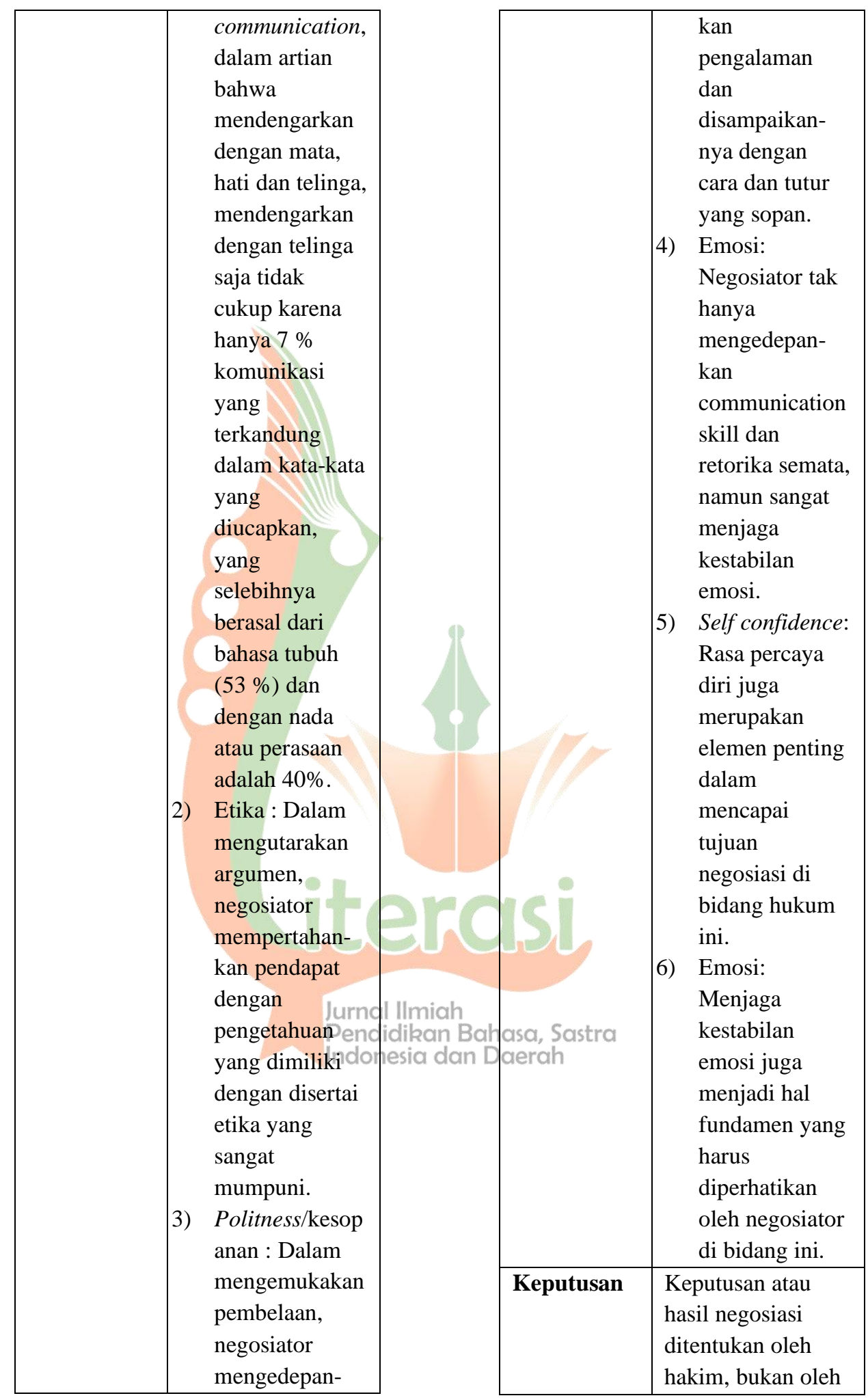




\begin{tabular}{|l|l|}
\hline & pelaku negosiasi. \\
& Bentuk \\
keputusannya \\
berwujud tertulis \\
dan formal. \\
\hline
\end{tabular}

\section{Data Politik}

Data yang terakhir mengenai data politik. Data ini diambil dari hasil pengamatan di statsiun televisi dan hasil berselancar di internet. Data politik yang didapat mengenai Pilgub DKI Jakarta. Adapun rangkuman dari negosiasi ini adalah sebagai berikut.

Sehubungan dengan akan berakhirnya masa jabatan Basuki Tjahaja Purnama sebagai gubernur DKI Jakarta, maka akan diadakan pemilihan kepala daerah pada tahun 2017. Pada pilkada DKI kali ini ada tiga pasangan calon (paslon) gubernur yang mendaftar. Ketiga pasangan calon gubernur dan calon wakil gubernur tersebut yaitu Agus Harimurti Yudhoyono dan Sylviana Murni, Basuki Tjahaja Purnama, dan Djarot, serta Anis Baswedan dan Sandiaga Uno.

Sebelum pada akhirnya tiba dihari pemilihan, para paslon cagub/udan cawagub diberikan kesempatan untuk melakukan kampanye dalam waktu yang telah ditentukan oleh KPU. Kesempatan ini tentunya dimanfaatkan oleh para paslon semaksimal mungkin. Para paslon berusaha untuk meyakinkan masyarakat Jakarta agar memilihnya.

Banyak usaha yang dilakukan oleh para paslon untuk menarik perhatian masyarakat, salah satunya adalah dengan memberitahukan program kerja kepada masyarakat jika mereka terpilih menjadi gubernur dan calon gubernur DKI Jakarta.

Paslon Agus dan Sylvi membuka kampanye pertamanya dengan pembacaan pidato politik di depan pendukungnya di Djakarta Theater. Di dalam pidatonya, Agus memaparkan 10 program kerjanya jika terpilih. Menurut Agus, 10 program itu merupakan bagian dari program aksi kepemimpinan. 10 program yang menajadi program unggulan paslon Agus dan Sylvi ini adalah sebagai berikut.

1) Bantuan langsung terhadap masyarakat tak mampu. Program ini akan meliputi program langsung untuk meningkatkan daya beli rakyat, bantuan langsung untuk balita dan lansia, serta penguatan jarring pengamanan sosial yang lain.

2) Pengurangan pengangguran dan penciptaan lapangan kerja.

3) Peningkatan pendidikan dan kesejahteraan guru.

4) Peningkatan kesehatan yang meliputi besaran Kartu Jakarta Sehat (KJS) hingga penambahan mobil ambulan dan pengadaan motor-motor ambulan.

5) Peningkatan pertumbuhan ekonomi dan investasi.

6) Peningkatan pembangunan infrastuktur dan perumahan.

7) Menjadikan Jakarta sebagai kota pintar, kreatif, dan ramah lingkungan.

8) Peningkatan keamanan masyarakat.

9) Menguatkan penegakan hukum di Jakarta. 
10) Menguatkan kembali kualitas pemerintahan dan birokrasi.

Tidak hanya Agus dan Sylvi, para pasangan calon yang lain juga tentunya emiliki program kerja unggulan masing-masing untuk menarik perhatian masyarakat. Salah satu program unggulan dari pasangan Basuki dan Djarot yaitu meneruskan program kerja Jokowi.

Selain itu, kartu Jakarata One juga menjadi program unggulan lainnya. Kartu ini nantinya bisa digunakan untuk melakukan pembayaran pada pelayanan publik milik pemerintah, seperti naik bus Transjakarta, rusun, pajak, RSUD, MRT, hingga penyaluran kredit usaha kecil menengah. Sedangkan pasangan Cagub dan Cawagub Anies-Sandi memiliki program kerja unggulan yang mengacu pada pembangunan fisik dan sumber daya manusia di Jakarta.

Pasangan ini akan memfokuskan kerjanya pada ketersediaan lapangan pekerjaan, pengendalian harga, dan pengadaan air bersih. Selain itu, pasangan ini juga mengusung program kerja unggulan berupa pengadaan rumah terjangkau bagi masyaraka Jakarta.

Pada Pemilihan umum Gubernur (Pilgub) Jakarta dilakukan dalam dua putaran. Putaran pertama dilaksanakan pada 15 Februari 2017, suara terbanyak diraih oleh pasangan Basuki-Djarot, yang kemudian di posisi kedua diraih oleh pasangan Anies-Sandi. Pasangan calon Agus-
Sylvi mendapatkan suara terendah. Berdasarkan dari hasil pemngutan suara pada putaran pertama, otomatis pasangan Agus-Silvi tidak lolos ke pemilihan putaran kedua.

Putaran kedua Pilgub DKI Jakarta dilaksanakan pada tanggal 19 April 2017. Pada putaran ini pasangan Anies-Sandi mendapatkan suara terbanyak dibandingkan dengan pasangan Basuki-Djarot. Mayoritas masyarakat Jakarta memercayakan kepada Anies-Sandi untuk memimpin Jakarta selama lima tahun ke depan.

Berdasarkan data yang telah dianalisis, negosiasi terjadi karena adanya pemilihan kepala daerah. Pihak yang terlibat dalam negosiasi yaitu antara pasangan calon dengan masyarakat daerah yang mengadakan pemilihan. Negosiasi yang dilaksanakan dalam bidang ini sudah diatur oleh panitia pelaksanaan pemilihan kepala daerah. Artinya, sudah disiapkan waktu oleh panitia khusus untuk melakukan negosiasi kepada masyarakat.

Waktu negosiasi antara para pasang calon dengan masyarakat terjadi, ketika kampanye. Pemberian keputusan terhadap negosiasi yang terjadi ada di pihak masyarakat selaku pemilih dan bersifat rahasia. Penetapan keputusan ini juga sudah diatur oleh panitia berkaitan dengan tempat dan waktu pelaksanaannya. Pengambilan keputusan ini dinyatakan dalam bentuk nyata, yaitu berupa kertas yang terdapat gambar paslon yang ia tandai. 
Pada waktu yang telah ditetapkan, para paslon berkampanye secara serentak kepada para pendukungnya. Salah satunya dengan menjabarkan program-progam yang akan dilakukan jika terpilih menjadi gubernur. Berselang beberapa bulan setelah kampanye, barulah secara serentak masyarakat Jakarta menjatuhkan pilihannya kepada paslon yang diinginkannya. Setelah pelaksanaan pemilihan, suara yang terkumpul untuk dukungan para paslon akan dihitung. Pemenang dari negosiasi ini adalah paslon yang memiliki dukungan terbanyak dari masyarakat.

Ketika proses negosiasi berlangsung, para paslon menggunakan beragam cara untuk meyakinkan masyarakat Jakarta untuk memilihnya menjadi gubernur dan wakil gubernur. Salah satunya adalah dengan menjelaskan kepada masyarakat tentang program-program yang akan dilaksanakan jika masyarakat memilihnya menjadi gubernur. Selain itu, cara yang dilakukan lainnya adalah dengan mendatangi warga di kampungkampung.

Pendidikan Bahasa, Sastra

Kaidah Khsusus

Tabel 5.

Kaidah Khsusus Negosiasi Politik

\begin{tabular}{|l|l|}
\hline Proses & Pihak yang terlibat \\
Negosiasi & dalam negosiasi ini \\
antara pasangan \\
calon dengan \\
masyarakat daerah \\
yang mengadakan \\
pemilihan.
\end{tabular}

\begin{tabular}{|c|c|}
\hline & $\begin{array}{l}\text { Pelaksanaan } \\
\text { negosiasi dalam } \\
\text { bidang ini sudah } \\
\text { diatur oleh panitia } \\
\text { pelaksanaan } \\
\text { pemilihan }\end{array}$ \\
\hline $\begin{array}{l}\text { Lama } \\
\text { Pelaksanaan }\end{array}$ & $\begin{array}{l}\text { Proses negosiasi } \\
\text { berlangsung } \\
\text { semenjak tahap awal } \\
\text { sampai pada waktu } \\
\text { penentuan } \\
\text { keputusan. Dalam } \\
\text { hal ini durasinya } \\
\text { berselang hingga } \\
\text { beberapa bulan }\end{array}$ \\
\hline $\begin{array}{l}\text { Faktor-faktor } \\
\text { yang } \\
\text { mempengaru } \\
\text { hi } \\
\text { keberhasilan }\end{array}$ & $\begin{array}{l}\text { Adapun faktor-faktor } \\
\text { yang mempengaruhi } \\
\text { keberhasilan } \\
\text { negosiasi pada } \\
\text { bidang ini adalah: }\end{array}$ \\
\hline & $\begin{array}{l}\text { a) Communication } \\
\text { skill: negosiator } \\
\text { harus memiliki } \\
\text { kemampuan } \\
\text { berkomunikasi } \\
\text { yang mumpuni } \\
\text { dalam bidang ini, } \\
\text { karena tujuannya } \\
\text { akan meminta } \\
\text { persetujuan atau } \\
\text { mempengaruhi } \\
\text { khalayak ramai. }\end{array}$ \\
\hline $\begin{array}{l}\text { ahasa, Sastra } \\
\text { Daerah }\end{array}$ & $\begin{array}{l}\text { b) Etika: negosiator } \\
\text { dalam bidang ini } \\
\text { sangat menjaga } \\
\text { etika, oleh karena } \\
\text { tujuannya untuk } \\
\text { menjadi } \\
\text { pemimpin atau } \\
\text { public figure } \\
\text { maka etika akan } \\
\text { menjadi salah } \\
\text { satu dari sekian } \\
\text { alasan khalayak }\end{array}$ \\
\hline
\end{tabular}




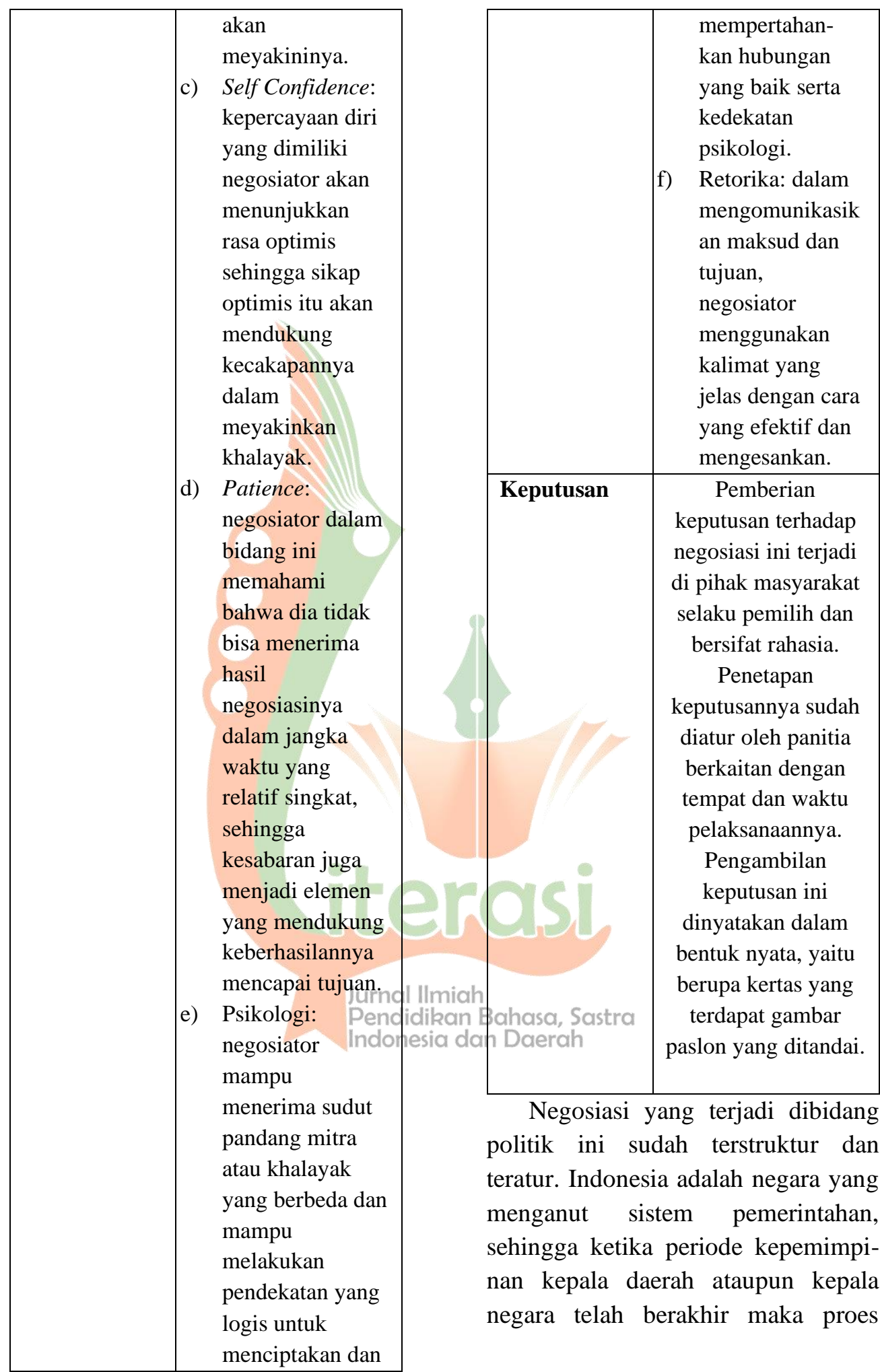


negosiasi ini akan berlangsung kembali secara teratur.

Pada jurnal yang ditulis oleh Lindholst (2014: 5) mengenai "Negotiation Planning and Preparation in Practice", dijelaskan bahwa penelitian tersebut bertujuan untuk memperbaiki keseimbangan dengan mengklarifikasi kegiatan persiapan dan perencanaan yang dilakukan untuk melakukan negosiasi bisnis yang kompleks dibandingkan dengan rekomendasi yang terdapat dalam literatur. Senada dengan penelitian tersebut, berdasarkan data yang telah dianalisis, pada aktivitas negosiasi yang terjadi di masyarakat, ada beberapa negosiasi yang kurang sesuai dengan teori yang dikemukakan oleh para ahli. Diantaranya adalah negosiasi yang terjadi ketika jual beli.

Pada negosiasi ini, aspek kemampuan negosiasi tidak terlalu berpengaruh pada keberhasilan negosiasi. Yang diperlukan dalam negosiasi dibidang jual beli ini, hanya kemampuan berkomunikasi yang baik serta mencari straegi yang cocok agar negosiasi dapat berhasil. Negosiasi dalam bidang ini tidak terlalu memerhatikan aspek kemampuan negosiasi, karena negosiasi ini sangat praktis dan sederhana. Berhubun negosiasi yang terjadi dalam bidang ini sangat praktis, sehingga tidak diperlukan persiapan untuk melakukan negosiasi.

Akan tetapi, berdasarkan data yang telah dianalisis, teori yang dikemukakan oleh ahli ternyata memiliki kesesuaian dengan praktek yang terjadi dibidang hukum dan dibidang politik. Negosaisi yang terjadi dalam kedua bidang ini merupakan negosiasi yang kompleks.

Selain itu, negosiasi yang terjadi ini merupakan negosiasi yang profesional berbeda dengan negosiasi yang terjadi dalam bidang jual beli. Sehingga aspek kemampuan negosiasi dan faktor-faktor yang memengaruhi negoasiasi harus diperhatikan agar negosiasi yang terjadi mencapai keberhasilan. Selain itu, tahapantahapan teori dengan negosiasi yang terjadi dibidang ini mempunyai kesesuaian.

\section{PENUTUP}

\section{Simpulan}

Penelitian ini memfokuskan pengamatan pada tiga bidang, yakni negosiasi jual beli, hukum, dan politik. Dan realitanya bahwa pada tahap implementasi di lapangan, proses negosiasi jual beli dilakukan tanpa menerapkan keseluruhan teori-teori yang dikemukakan para ahli.

Negosiasi dalam bidang jual beli dimulai ssejak awal ketika pembeli menanyakan barang dan harga barang yang akan dibeli. Adapun faktor yang mempengaruhi keberhasilan dalam negosiasi ini yaitu kemampuan retorika atau communication skill, tingkat kesabaran, dan kemampuan mengelola emosi.

Keputusan dalam bidang jual beli ini diambil oleh kedua belah pihak. Negosiasi dalam bidang hukum dan 
politik, teori-teori yang dikemukakan para ahli mengenai tahapan negosiasi dan faktor yang mempengaruhi keberhasilan negosiasi berterima/sesuai dengan keadaan di lapangan, dalam artian bahwa memang diterapkan oleh para negosiator di bidang hukum dan politik.

Negosiasi bidang hukum dan politik ini hanya dibedakan oleh pengambilan keputusan. Keputusan dalam negosiasi hokum ditentukan oleh hakim sedangkan dibidang politik ditentukan oleh para pemilih.

Berdasarkan pemaparan tersebut, jika dikaitkan dengan kurikulum yang ada di buku materi pelajaran kelas X, terdapat ketidaksesuaian antara materi yang dipelajari siswa dengan situasi di lapangan. Pada buku materi ajar, negosiasi dibahas dengan konsep yang sederhana, padahal pada tahap implementasinya sangat kompleks.

\section{Saran}

Penelitian ini hanya memfokuskan pengamatan pada tiga bidang, baiknya untuk penelitian sesudahnya bisa mengkaji bidang-bidang lain. seperti negosiasi keluarga, organisasi dan komunitas masyarakat pada umumnya.

\section{DAFTAR PUSTAKA}

Dama, Hais. Efektivitas Komunikasi Dan Negosiasi Dalam Bisnis: Dosen Fakultas Ekonomi dan Bisnis UNG.

Elena, Koseska, Liljana Batkoska, Kliment Arnaudov. 2012. Negotiation Skills - A Factor for Insurance Development in Conditions of a Changeable Surrounding. Procedia: Social and Behavioral Sciences.

Jackman. A. 2005. How To Negotiate: Teknik Sukses Bernegosiasi. Jakarta: Erlangga.

Jalaludin, Rakhmat. 2005. Psikologi Komunikasi. Bandung: Remaja Rosda Karya.

Jung Tsay, Chia \& H. Bazerman Max. 2009. A Decision-Making Perspective to Negotiation: Areview Of The Past and Look Into The Future. Working Paper. 10-002.

Lindholst, Morten. 2014. Negotiation Planning and Preparation in Practice. NL, 4-7/7/2014

McGuire, R. 2004. Negotiation : An In Important Life Skill. Jurnal The Illikah BahaPharmaceutical. Vol. 273 i esia dan Da25),

Robert, Heron dan Caroline Vandenabeele. 1997. Negosiasi Efektif: Sebuah Panduan Praktis. Indonesia:

Friedrich_Ebert_Stiftung (FES). 